\title{
Nutritive value of meat and bone meal for growing pigs
}

\author{
KIRSI PARTANEN and MATTI NÄSI
}

\begin{abstract}
PARTANEN, K. \& NÄSI, M. 1994. Nutritive value of meat and bone meal for growing pigs. Agricultural Science in Finland 3: 449-455. (Department of Animal Science, PO Box 28, FIN-00014 University of Helsinki, Finland.)
\end{abstract}

\begin{abstract}
Six barrows, with an average initial body weight of $88 \mathrm{~kg}$, were used in a digestibility and balance experiment to study the nutritive value of meat and bone meal (MBM). The MBM, which contained $478 \mathrm{~g}$ crude protein and $322 \mathrm{~g} \mathrm{ash} / \mathrm{kg}$ dry matter (DM), was included in barley-based diets at two levels: 100 and $200 \mathrm{~g} / \mathrm{kg}$. The experiment was conducted according to a two-period reversal design. The apparent digestibilities of organic matter, crude protein and crude fat in the MBM were $0.910,0.909$ and 0.730 , respectively. The MBM was calculated to contain $434 \mathrm{~g}$ digestible crude protein, 14.26 MJ metabolizable energy and 8.82 MJ net energy/kg DM. The efficiency of nitrogen utilization decreased with an increasing MBM supply. Due to relatively high mineral intakes, the apparent digestibilities of calcium and phosphorus remained low.
\end{abstract}

Key words: digestibility, nitrogen balance, minerals

\section{Introduction}

Meat and bone meals are by-products of the slaughtering and meat processing industry. They are good sources of protein, energy and minerals, and are, therefore, useful as animal feed (MILLER and DE BOER 1988). The Finnish rendering plants produce approximately 29 million $\mathrm{kg}$ of meat and bone meal annually (Sirén, personal communication), a large proportion of which is used in pig diets.

The results of feeding experiments have shown that replacement of soya bean meal with increasing levels of meat and bone meal causes a reduction in average daily gain and feed conversion efficiency (AlaviuHKola 1989, 1992), although the calculated nutrient supply, based on the digestibilities and energy values reported in feed tables (SALO et al. 1990) remained the same. As indicated by several authors (Just et al. 1982, KNABE et al. 1989, BRUYER et al. 1990,
SKILTON et al. 1991), meat and bone meal is not a single product but a variety of different products and, hence, actual nutrient contents and their digestibilities can differ considerably from those given in feed tables. Therefore, reduced performance may result from inappropriate nutrient values being ascribed to the product. The digestibility of protein, the amino acid content and their availability, in particular, can vary considerably between different meat and bone meals (BATTERHAM et al. 1986, KNABE et al. 1989).

The aim of this preliminary study was to determine the nutritive value of meat and bone meal for pigs. A sample of meat and bone meal (MBM) was obtained from a rendering plant which has a dry rendering system with mechanical removal of fat after rendering. The raw material was a mixture of cattle and pig offal, and bones. The sample represented an average composition of the MBM produced by the plant. 


\section{Material and methods}

The digestibility and balance experiment was conducted with six Large White x Landrace finishing barrows using a two-period reversal design. The experimental diets were composed as follows: diet A contained $800 \mathrm{~g}$ barley, $100 \mathrm{~g}$ barley starch and $100 \mathrm{~g} \mathrm{MBM} / \mathrm{kg}$, and diet B contained $800 \mathrm{~g}$ barley and $200 \mathrm{~g} \mathrm{MBM} / \mathrm{kg}$. The diets were supplemented with $1.2(\operatorname{diet} \mathrm{A})$ or $1.4(\operatorname{diet} \mathrm{B})$ $\mathrm{g} / \mathrm{kg}$ of trace mineral mixture with the following mineral content per g: $13 \mathrm{mg} \mathrm{Fe}, 46 \mathrm{mg} \mathrm{Zn}$, $13 \mathrm{mg} \mathrm{Mn}, 13 \mathrm{mg} \mathrm{Cu}$ and $0.06 \mathrm{mg} \mathrm{Se}$. The pigs were also given a vitamin solution which added the following vitamins per $\mathrm{kg}$ of diet: $5000 \mathrm{IU}$ vitamin A, $500 \mathrm{IU} \mathrm{D}_{3}, 15 \mathrm{mg} \mathrm{E}, 1 \mathrm{mg} \mathrm{K}_{3}, 1 \mathrm{mg} \mathrm{B}_{1}$, $2 \mathrm{mg} \mathrm{B}, 2 \mathrm{mg} \mathrm{B}_{6}, 0.0075 \mathrm{mg} \mathrm{B} \mathrm{B}_{12}, 0.025 \mathrm{mg}$ biotin, $5 \mathrm{mg}$ pantothenic acid and $10 \mathrm{mg}$ nicotinic acid.

The pigs were kept in metabolism cages throughout the experiment. The experiment comprised two 10-day periods, and faeces were collected for five consecutive days, starting on day 6 . The daily ration $(2.7 \mathrm{~kg}$ feed) was divided into two equal meals and mixed with water (1 water: 1 feed, w/w). Water was available ad libitum between the meals. The average initial body weight of the pigs was $88.0( \pm 5.9) \mathrm{kg}$ and the average final weight $112.5( \pm 7.3) \mathrm{kg}$.

The feed ingredients were analyzed for ash, crude fat (CF), nitrogen (N), amino acids, calcium $(\mathrm{Ca})$, phosphorus $(\mathrm{P})$ and magnesium $(\mathrm{Mg})$. Total faeces were collected daily, stored at $-18^{\circ} \mathrm{C}$ until the end of the collection period, thawed, mixed, sampled, and analyzed for dry matter (DM). Faeces were analyzed for ash, CF, Ca, P and $\mathrm{Mg}$. The samples were dried at $60^{\circ} \mathrm{C}$ for 72 hours prior to the chemical analyses, except for $\mathrm{N}$, which was analyzed from fresh samples. Urine was collected daily into $40 \mathrm{ml}$ of $10 \mathrm{~N} \mathrm{H}_{2} \mathrm{SO}_{4}$, sampled and stored at $4^{\circ} \mathrm{C}$. At the end of the collection period, the samples were pooled on an animal basis and analyzed for $\mathrm{N}$, urea $\mathrm{N}, \mathrm{Ca}, \mathrm{P}$ and $\mathrm{Mg}$.

Ash, $\mathrm{CF}$ and $\mathrm{N}$ analyses were performed according to the methods described by AOAC (1984). Crude protein (CP) was calculated as Kjel- dahl $\mathrm{N}$ x 6.25. CF was determined after hydrolysis with $4 \mathrm{~N} \mathrm{HCl}$. Amino acid analyses were performed by ion-exchange chromatography after hydrolysis in $6 \mathrm{~N} \mathrm{HCl}$ for $23 \mathrm{~h}$. For methionine and cystine analyses, the samples were oxidized by performic acid prior to acid hydrolysis. The urea $\mathrm{N}$ content was analyzed with a Gilford 3000 Auto Analyzer. P was determined after dry ashing by colorimetry using the vanadomolybdate procedure (TAYSSKY and SHORR 1953), and Ca and $\mathrm{Mg}$ were measured by atomic absorption spectroscopy.

The data were subjected to a least square analysis of variance (SNEDECOR and COCHRAN 1989) using the model:

$Y_{i j k}=\mu+A_{i}+P_{j}+T_{k}+e_{i j k}$

where $\mathrm{A}, \mathrm{P}$ and $\mathrm{T}$ are the effects of animal, period and treatment, respectively. To calculate the digestibility coefficients of nutrients in the MBM, the data were inserted into the multiple regression equation

$\mathrm{Y}=\mathrm{aX}+\mathrm{X}_{1}$

in which $\mathrm{Y}$ is the total amount of nutrient digested from the ratio $(\mathrm{g} / \mathrm{d}), \mathrm{X}_{1}$ and $\mathrm{X}_{2}$ are the amounts of nutrient consumed from barley/MBM $(\mathrm{g} / \mathrm{d})$, and $a$ and $b$ are the digestible fractions of nutrient in barley/MBM, respectively (SCHNEIDER and FLATT 1975). Barley starch was excluded from the equation because it was assumed to be fully digestible (Graham et al. 1986, 1989). The metabolizable (ME) and net energy (NE) values of the MBM were calculated according to ANDERSEN and Just (1983), while the value for net energy in fattening feed units ( $\mathrm{FU}=0.7$ starch equivalents) was calculated as described by SALO et al. (1990).

\section{Results and discussion}

Meat and bone meal is the rendered product from inedible slaughter offal and bones. The raw materials incorporated into the meal may also in- 
Table 1. Chemical composition of feed ingredients.

\begin{tabular}{lrrrr}
\hline Feed ingredient & $\begin{array}{c}\text { Meat } \\
\text { and bone } \\
\text { meal }\end{array}$ & Barley & $\begin{array}{r}\text { Barley } \\
\text { starch }\end{array}$ & $\begin{array}{c}\text { Trace } \\
\text { mineral } \\
\text { mixture }\end{array}$ \\
\hline Dry matter, g/kg & 967 & 879 & 863 & 964 \\
Content in DM, g/kg: & 478 & 115 & 4 & 1 \\
Crude protein & 157 & 32 & 0 & 0 \\
Crude fat & 322 & 26 & 2 & 922 \\
Ash & 118.7 & 0.7 & 0.2 & 303.1 \\
Ca & 55.9 & 4.1 & 0.3 & 0.1 \\
P & 2.3 & 1.3 & 0.06 & 7.3 \\
Mg & & & & \\
\hline
\end{tabular}

clude hide trimmings, heads, feet and blood. The nutritive value of meat and bone meal is mainly dependent on raw material composition and processing conditions (JuST et al. 1982, HAUGEN et al. 1985, BATterham et al. 1986, KNABE et al. 1989, BRUYER et al. 1990, SKILTON et al. 1991). The chemical composition of the MBM sample analyzed in the present study (Table 1) is in agreement with the results reported by others (JUST et al. 1982, KNABE et al. 1989, BRUYER et al. 1990). Finnish feed tables (SALo et al. 1990) give a somewhat lower fat content ( $90 \mathrm{~g} \mathrm{CF} / \mathrm{kg} \mathrm{DM})$ for meat and bone meal than that measured in the present experiment. The MBM sample was obtained from a plant which removes the fat mechanically after rendering, which explains the somewhat higher fat content.

The contents of essential amino acids (Table 2) are within the wide range of values (2.9-7.4 g/ $100 \mathrm{~g} \mathrm{CP}$ ) reported for meat and bone meal in the literature (JUST et al. 1982, BRUYER et al. 1990, SAlo et al. 1990, Skilton et al. 1991). Lysine is the first limiting amino acid in barley-based diets (FULLER et al. 1979) and, therefore, its amount in a protein supplement is very important.

The pigs ate the feed without difficulty and their health remained good throughout the experiment. The average daily weight gain was $979 \mathrm{~g}$.

The faecal digestibility of CP and CF increased $(\mathrm{p}<0.05)$ with an increasing MBM supply, whereas that of organic matter (OM, $\mathrm{p}<0.05)$ and ash $(\mathrm{p}=0.053)$ decreased (Table
Table 2. Amino acid composition of meat and bone meal, $\mathrm{g} / 100 \mathrm{~g}$ crude protein.

\begin{tabular}{lrll}
\hline Alanine & 7.1 & Leucine & 5.5 \\
Arginine & 6.7 & Lysine & 4.1 \\
Aspartic acid & 6.7 & Methionine & 1.1 \\
Cystine & 1.2 & Phenylalanine & 3.2 \\
Glutamic acid & 11.0 & Serine & 4.7 \\
Glycine & 20.8 & Threonine & 3.1 \\
Histidine & 1.3 & Tyrosine & 1.9 \\
Isoleucine & 2.6 & Valine & 4.2 \\
\hline
\end{tabular}

3). The apparent digestibility coefficients calculated for nutrients in the MBM were: OM 0.910, CP 0.909 and CF 0.730 . Based on the determined digestibility coefficients, the MBM was calculated to contain $434 \mathrm{~g}$ digestible CP, 14.26 MJ ME and $8.82 \mathrm{MJ}$ NE/kg DM. The energy value in feed units was $0.98 \mathrm{FU} / \mathrm{kg}$ DM.

The digestibility coefficients and energy value of the MBM calculated in the present study were higher than those reported in other studies. JUST et al. (1982) determined the nutritive value of 17 different meat and bone meal batches and obtained apparent CP digestibilities from 0.72 to 0.82, apparent CF digestibilities from 0.08 to 0.70 , and ME contents from 6.1 to $11.0 \mathrm{MJ} / \mathrm{kg} \mathrm{DM}$. The live weight of the pigs used in that experiment was from 50 to $65 \mathrm{~kg}$, whereas the pigs used in the present study were heavier (88$113 \mathrm{~kg}$ ).

It is generally accepted that the digestibility of dietary nutrients and energy is improved with increasing body weight (ROTH and KIRCHGESSNER 1984), which partly explains the high digestibilities obtained in the present study. The improved apparent digestibility of nutrients is due to the increased contribution of the hindgut to digestion of the diet as live weight increases (NOBLET and SHI 1993).

In comparative digestibility experiments, sows have been found to digest the nutrients and energy of several feed ingredients, including meat and bone meal, more efficiently than growing 
Table 3. Faecal digestibility of nutrients and nitrogen balance of experimental diets.

\begin{tabular}{lrrrc}
\hline Diet & A & B & SEM & Signif. \\
\hline Organic matter & 0.863 & 0.852 & 0.0021 & $*$ \\
Crude protein & 0.833 & 0.853 & 0.0039 & $*$ \\
Crude fat & 0.612 & 0.646 & 0.0070 & $*$ \\
Ash & 0.354 & 0.299 & 0.0102 & NS \\
& & & & \\
N intake, g/d & 54.4 & 73.7 & 0.35 & $* * *$ \\
Faecal N, g/d & 9.1 & 10.8 & 0.30 & $*$ \\
Urinary N, g/d & 25.8 & 38.0 & 0.82 & $* * *$ \\
Urea N, g/d & 21.5 & 33.1 & 1.00 & $* *$ \\
N retained, g/d & 19.5 & 24.9 & 0.48 & $* *$ \\
- of intake & 0.359 & 0.338 & 0.0065 & NS \\
- of absorbed & 0.431 & 0.397 & 0.0070 & $*$ \\
- per kg W 0.75 & 0.617 & 0.784 & 0.0203 & $* *$ \\
Biological value & 0.537 & 0.476 & 0.0069 & $* *$ \\
\hline
\end{tabular}

$* * *(p<0.001), * *(p<0.01), *(p<0.05)$ and NS (nonsignificant).

pigs. FERnÁNDEZ et al. (1986) obtained CP digestibilities of 0.79 and 0.86 , CF digestibilities of 0.26 and 0.74 , and energy digestibilities of 0.61 and 0.82 in meat and bone meal for growing pigs (40-60 kg) and sows, respectively. Correspondingly, SHI and NoBlet (1993) reported CP digestibilities of 0.67 and 0.78 , and energy digestibilities of 0.490 and 0.774 in meat and bone meal for growing pigs (45 kg) and sows. However, the digestibilities obtained for growing pigs in the present experiment were even higher than those obtained for sows in the previous studies.

The feeding level may also have affected the digestibilities of nutrients. A reduction in the feeding level is usually associated with an increased digestibility, which is related to the longer retention time of food in the digestive tract (RoTH and KIRCHGESSNER 1984, EverTs et al. 1986, Noblet and $\mathrm{SHI}_{\mathrm{HI}}$ 1993). The daily feed intake in the present study was relatively low, averaging $75 \mathrm{~g}$ $\mathrm{DM} / \mathrm{kg} \mathrm{W}^{0.75}$.

$\mathrm{N}$ retention increased with an increasing level of MBM in the diet $(\mathrm{p}<0.01)$, but at a slower rate than $\mathrm{N}$ intake (Table 3). This was found to be related to increased urinary $\mathrm{N}$ losses $(\mathrm{p}<0.001)$. N retention was $0.701 \mathrm{~g} / \mathrm{kg} \mathrm{W}^{0.75} / \mathrm{d}$ on an average. The proportion of digested $\mathrm{N}$ that was retained $(\mathrm{p}<0.01)$ and the biological value of dietary protein $(\mathrm{p}<0.01)$ decreased with an increasing MBM supply.

Although the protein in the MBM diets was highly digestible, its biological value was low due to the high urinary $\mathrm{N}$ excretion. This may have been due to several reasons. With processed feeds, such as meat and bone meal, the protein may have been damaged and the amino acids altered structurally. It has been found that some of these compounds are absorbed but not utilized and are therefore excreted in the urine (BATTERHАM 1992).

The contribution of the bacteria in the hindgut to the digestion of a dietary protein becomes more important with increasing live weight. The undigested protein entering the large intestine of the pig is broken down to ammonia, absorbed, converted to urea in the liver and excreted in the urine (NoBlet and SH 1993). The growth of microflora in the large intestine is dependent on the available nitrogen and energy supply (Low and ZEBROWSKA 1989). Infusion of starch into the caecum of pigs fed on a barley-meat and bone meal diet depressed the faecal apparent digestibility and urinary excretion of N (ZEBROWSKA et al. 1980). The above results indicated that the route of $\mathrm{N}$ excretion changed because the energy supply no longer limited the microbial growth. The high faecal digestibility and urinary excretion of $\mathrm{N}$ observed in the present study imply that the energy supply limited the microbial growth in the caecum, and therefore, less $\mathrm{N}$ was excreted in faeces.

The amino acid balance of the experimental diets used in the present experiment may not have met the balance required by the animal. WANG and FULLER (1989) achieved the highest efficiency of $\mathrm{N}$ retention with diets having the following balance of amino acids ( $/ 100 \mathrm{~g} \mathrm{CP}$ ): lysine 6.5 (100), threonine 4.7 (72), valine 4.9 (75), methionine + cystine 4.1 (63), isoleucine 3.9 (60), leucine 7.2 (110), phenylalanine + tyrosine 7.8 (120) and tryptophan 1.2 (18). In the present study, the experimental diets had only $3.9 \mathrm{~g}$ lysine/100 $\mathrm{g} \mathrm{CP}$, which is $2.6 \mathrm{~g}$ less com- 
pared with the ideal protein composition. In addition, the threonine and methionine + cystine contents were considerably lower than in the proposed ideal protein.

Animal by-products have a high content of $\mathrm{Ca}$ and $\mathrm{P}$, mainly in inorganic form. The digestibility of $\mathrm{P}$ in animal by-products is generally high, ranging from 0.68 to 0.91 . Around 0.80 of the P from meat meal, bone meal and meat and bone meal is digested (Jongbloed and Kemme 1990). In recent experiments, BEERs et al. (1993) have obtained somewhat lower digestibilities, ranging from 0.589 to 0.690 . No information on the digestibility of $\mathrm{Ca}$ in animal by-products was found in the literature, but it could be assumed to be similar to that of other inorganic Ca sources.

The utilization of $\mathrm{Ca}$ and $\mathrm{P}$ depends on the level of $\mathrm{Ca}$ and $\mathrm{P}$ intake, as well as on the requirement of the animal. Generally, the efficiency of Ca (FERnándeZ 1992) and P (Jongbloed 1987) absorption declines with increasing intake. Urinary P excretion increases as P intake increases (ARC 1981, Jongbloed 1987, FernándeZ 1992), whereas urinary $\mathrm{Ca}$ excretion is generally negligible and, if $\mathrm{P}$ is not deficient, it remains relatively constant at different Ca intakes (ARC 1981, FERNÁNDEZ 1992).

In the present study, the digestibility of dietary $P$ (Table 4) decreased $(p<0.05)$ with an increasing MBM supply, whereas that of $\mathrm{Ca}$ and $\mathrm{Mg}$ was not affected $(p>0.05)$. The urinary excretion of minerals was not affected by the MBM supply $(p>0.05)$. The retention of $\mathrm{Ca}(\mathrm{p}<0.01)$ and $\mathrm{P}(\mathrm{p}<0.05)$ increased with an increasing MBM supply, whereas that of Mg was not affected $(\mathrm{p}>0.05)$. $\mathrm{P}$ retention ranged from 6.2 to $8.9 \mathrm{~g}$ per $\mathrm{kg}$ live weight gain. JONGBLOED (1987) calculated that $\mathrm{P}$ retention per $\mathrm{kg}$ live weight gain over the range of 15 to $110 \mathrm{~kg}$ live weight is between 5.5 and $6.0 \mathrm{~g} / \mathrm{d}$, which is somewhat lower than obtained in this study. The pigs used in the present study had been on low-P diets in a previous experiment, which may have caused the high $\mathrm{P}$ retention and lack of response in urinary $P$ excretion.
Table 4. Mineral balances of the experimental diets.

\begin{tabular}{|c|c|c|c|c|}
\hline Diet & A & B & SEM & Signif. \\
\hline \multicolumn{5}{|l|}{ Calcium } \\
\hline Intake, g/d & 33.1 & 63.3 & 0.30 & $* * *$ \\
\hline Absorbed, g/d & 10.5 & 17.6 & 0.84 & $* *$ \\
\hline - of intake & 0.318 & 0.278 & 0.0167 & NS \\
\hline $\begin{array}{l}\text { Excreted in } \\
\text { urine, g/d }\end{array}$ & 0.6 & 0.9 & 0.16 & NS \\
\hline Retained, g/d & 10.0 & 16.7 & 0.95 & $* *$ \\
\hline - of intake & 0.301 & 0.264 & 0.0190 & NS \\
\hline - of absorbed & 0.945 & 0.949 & 0.0135 & NS \\
\hline \multicolumn{5}{|l|}{ Phosphorus } \\
\hline Intake, g/d & 22.3 & 36.5 & 0.17 & *** \\
\hline Absorbed, g/d & 9.0 & 11.5 & 0.50 & $*$ \\
\hline - of intake & 0.406 & 0.316 & 0.0168 & $*$ \\
\hline Excreted in & & & & \\
\hline urine, g/d & 3.0 & 2.9 & 0.14 & NS \\
\hline Retained, g/d & 6.0 & 8.7 & 0.48 & $*$ \\
\hline - of intake & 0.270 & 0.237 & 0.0159 & NS \\
\hline - of absorbed & 0.662 & 0.748 & 0.0166 & $*$ \\
\hline \multicolumn{5}{|l|}{ Magnesium } \\
\hline Intake, g/d & 3.0 & 3.6 & 0.02 & $* * *$ \\
\hline Absorbed, g/d & 0.9 & 1.1 & 0.05 & NS \\
\hline - of intake & 0.314 & 0.304 & 0.0166 & NS \\
\hline Excreted in & & & & \\
\hline urine, g/d & 0.3 & 0.4 & 0.06 & NS \\
\hline Retained, g/d & 0.6 & 0.7 & 0.09 & NS \\
\hline - of intake & 0.203 & 0.196 & 0.0294 & NS \\
\hline - of absorbed & 0.635 & 0.646 & 0.0629 & NS \\
\hline
\end{tabular}

$* * *(\mathrm{p}<0.001), * *(\mathrm{p}<0.01), *(\mathrm{p}<0.05)$ and NS (nonsignificant).

In addition to the effect of high intake, the efficiency of $\mathrm{Ca}$ and $\mathrm{P}$ absorption and retention may be affected by the live weight of the pig. Generally, the capacity of absorption and retention of both $\mathrm{Ca}$ and $\mathrm{P}$ are considered to decline with increasing live weight (ARC 1981). However, FERNÁNDEZ (1992) has obtained contrary results with growing pigs. The optimum $\mathrm{Ca}: \mathrm{P}$ ratio reported for maximum $\mathrm{P}$ retention is $1.3: 1$ (JONGBLOED 1987), whereas that of meat and bone meal is generally about $2: 1$. Other results indicate that processing may also affect $\mathrm{Ca}$ and $\mathrm{P}$ digestibility in meat and bone meal (JONGBLOED and KeMME 1990). 


\section{References}

Alaviuhrola, T. 1989. Lihaluurehujauho sikojen rehuna. Lihayhtymän tiedotuslehti 2: 15-16.

- 1992. Uusi lisäaine ehdolla sikojen rehuihin. Sika 22, 2: 60-61.

ANDERSEN, P.E. \& JUST, A. 1983. Tabeller over foderstoffers sammensætning m.m. kvæg-svin. 102 p. Det kgl. danske Landhusholdningsselskab, København.

AOAC 1984. Official methods of analysis. 1141 p. Association of Official Analytical Chemist, Inc., Arlington, Virginia.

ARC 1981. The nutrient requirements of pigs. Agricultural Research Council, Commonwealth Agricultural Bureaux, Slough, UK. 304 p.

BATTERHAM, E.S. 1992. Availability and utilization of amino acids for growing pigs. Nutrition Research Reviews 5: $1-18$.

-, Darnell, R.E., Herbert, L.S. \& Major, E.J. 1986. Effect of pressure and temperature on the availability of lysine in meat and bone meal as determined by slope-ratio assays with growing pigs, rats and chicks and by chemical techniques. British Journal of Nutrition 55: 441-453.

Beers, S., Kemme, P.A., Jongbloed, A.W. \& Horsting, V.B.J. 1993. P-digestibility in feed phosphates and products of animal origin: results of several trials. Part 1: Apparent digestibility of phosphorus in products of animal origin. 25 p. Rapport - Instituut voor Veevoedingsonderzoek No. 249.

Bruyer, D.C., Foulon, M. \& Vanbelle, M. 1990. The amino acid composition of meat and bone meals and its predictability. Archives of Animal Nutrition, Berlin 40: 259-265.

Everts, H., Smits, B. \& Jongbloed, A.W. 1986. Effect of crude fibre, feeding level and body weight on apparent digestibility of compound feeds by swine. Netherlands Journal of Agricultural Science 34: 501-503.

FERNÁNDEZ, J.A. 1992. Calcium and phosphorus metabolism in growing pigs studied by the balance technique and simultaneous radio-calcium and radio-phosphorus kinetics. Ph.D Thesis, The Royal Veterinary and Agricultural University, Frederiksberg, Denmark. 148 p.

-, JøRgensen, H. \& Just, A. 1986. Comparative digestibility experiments with growing pigs and adult sows. Animal Production 43: 127-132.

Fuller, M.F., Livingstone, R.M., BAird, B.A. \& AtKinSON, T. 1979. The optimal amino acid supplementation of barley for the growing pig. 1. Response of nitrogen metabolism to progressive supplementation. British Journal of Nutrition 41: 321-331.

Graham, H., Fadel, J.G., Newman, C.W. \& Newman, R.K. 1989. Effect of pelleting and $\beta$-glucanase supplementation on the ileal and fecal digestibility of a barley-based diet in the pig. Journal of Animal Science 67: 1293-1298.

-, Hesselman, K., Jonsson, E. \& Åman, P. 1986. Influence of $\beta$-glucanase supplementation on digestion of a barley-based diet in the pig gastrointestinal tract. Nutrition Reports International 34: 1089-1096.

Haugen, E.W., Pettigrew, J.E., Cornelius, S.G. \& MoSER, R.L. 1985. Effects of meat meal manufacturing variations on amino acid bioavailability in pigs. Journal of Animal Science 61(Supplement 1): 100.

JoNGBLOED, A.W. 1987. Phosphorus in the feeding of pigs; effect of diet on the absorption and retention of phosphorus by growing pigs. 343 p. Doctoral Thesis, Wageningen Agricultural University.

- \& KeMmE, P.A. 1990. Apparent digestible phosphorus in the feeding of pigs in relation to availability, requirement and environment. 1. Digestible phosphorus in feedstuffs from plant and animal origin. Netherlands Journal of Agricultural Science 38: 567-575.

Just, A., Fernández, J.A. \& Jørgensen, H. 1982. Kødbenmels værdi til svin. 52 p. 525 . Beretning fra Statens Husdyrbrugs forsøg.

Knabe, D.A., LaRue, D.C., Gregg, E.J., Martinez, G.M. \& TANKSLEY, T.D., Jr. 1989. Apparent digestibility of nitrogen and amino acids in protein feedstuffs by growing pigs. Journal of Animal Science 67: 441-458.

Low, A.G. \& ZebrowsKA, T. 1989. Digestion in pigs. In: Bock, H.D. et al. (eds.). Protein metabolism in farm animals. Oxford university Press, Berlin. p. 53-121.

Miller, E.L. \& DE Boer, F. 1988. By-products of animal origin. Livestock Production Science 19: 159-196.

Noblet, J. \& SHI, X.S. 1993. Comparative digestibility of energy and nutrients in growing pigs fed ad libitum and adult sows fed at maintenance. Livestock Production Science 34: 137-152.

Roth, F.X. \& KirChgesSneR, M. 1984. Verdaulichkeit der Energie und Rohnährstoffe beim Schwein in Abhängigkeit von Fütterungsniveu und Lebendgewicht. Zeitschrift für Tierphysiologie, Tierernährung und Futtermittelkunde 51: 79-87.

SAlo, M.-L., TuORI, M. \& KIISKINEN, T. 1990. Rehutaulukot ja ruokintanormit. 70 p. Yliopistopaino, Helsinki.

SCHNEIDER, B.H. \& FlATt, P.W. 1975. The evaluation of feeds through digestibility evaluation. 423 p. University of Georgia Press, Athens, Georgia.

SHI, X.S. \& Noblet, J. 1993. Digestible and metabolizable energy values of ten feed ingredients in growing pigs fed ad libitum and sows fed at maintenance level; comparative contribution of the hindgut. Animal Feed Science and Technology 42: 223-236.

Skilton, G.A., Smith, W.C. \& Moughan, P.J. 1991. The ileal digestibility of nitrogen and amino acids in meat and bone meals determined using a rat assay. Animal Feed Science and Technology 34: 111-126.

SNEDECOR, G.W. \& CoCHRAN, W.G. 1989. Statistical methods. 503 p. 8th ed. Iowa University Press, Ames, Iowa.

TAYSSKY, H.H. \& SHORR, E. 1953. A microcolorimetric method for the determination of inorganic phosphorus. Journal of Biological Chemistry 202: 675-685.

WANG, T.C. \& Fuller, M.F. 1989. The optimum dietary 
amino acid pattern for growing pigs. 1. Experiments by amino acid deletion. British Journal of Nutrition 62: 77-89.

Zebrowska, T., ZebrowsKa, H. \& Buraczewska, L. 1980. The relationship between amount and type of carbohydrates entering the large intestine and nitrogen excre- tion in faeces and urine of pigs. In: Proceedings of the 3rd EAAP symposium on protein metabolism and nutrition. EAAP Publication No. 27. p. 222-226.

Manuscript received January 1994

\title{
SELOSTUS
}

\section{Lihaluurehujauhon ravitsemuksellinen arvo lihasikojen ruokinnassa}

\author{
Kirsi Partanen ja MatTi NÄSI
}

\author{
Helsingin yliopisto
}

Tutkimuksessa selvitettiin lihaluujauhon rehuarvoa lihasikojen ruokinnassa. Tutkittavassa lihaluujauhossa oli $322 \mathrm{~g}$ tuhkaa ja $478 \mathrm{~g}$ raakavalkuaista per kg kuiva-ainetta. Lihaluujauhon ravintoaineiden sulavuutta sekä valkuaisen ja kivennäisaineiden hyväksikäyttöä tutkittiin sulavuusja tasekokeessa. Kokessa oli 6 lihasikaa, joiden elopaino oli $88-113 \mathrm{~kg}$. Sioille syötettiin ohrapohjaisia rehuseoksia, joihin oli lisätty joko 100 tai $200 \mathrm{~g}$ lihaluujauhoa per kg.

Koeruokintojen orgaanisen aineen sulavuus aleni hiukan ja raakarasvan sulavuus parani, kun lihaluujauhon osuus rehuseoksessa kasvoi. Raakavalkuaisen sulavuus parani myös lihaluujauhon saannin kasvaessa, mutta samalla virtsassa eritetyn typen määrä kasvoi ja valkuaisen hyväkssikäyttö heikkeni. Lihaluujauhon ravintoaineiden regressiona lasketut sulavuuskertoimet olivat korkeita; orgaanisen aineen sulavuus oli 0,910 , raakavalkuaisen 0,909 ja rakarasvan 0,730 . Lihaluujauhon energia-arvoksi saatiin $0,98 \mathrm{ry} / \mathrm{kg} \mathrm{ka}$. Lihaluujauhossa on runsaasti kivennäisaineita, erityisesti kalsiumia ja fosforia. Rehussa ylimäärin saatu kalsium ja fosfori erittyy sonnan ja virtsan mukana. 